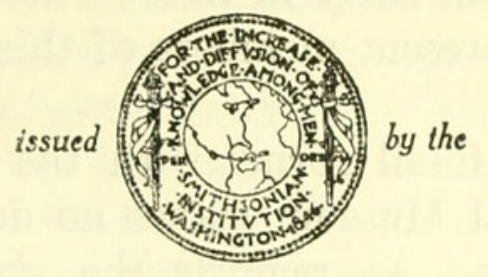

SMITHSONIAN INSTITUTION

U. S. NATIONAL MUSEUM

\begin{tabular}{lll}
\hline Vol, 90 & Washington: 1941 & No. 3113 \\
\hline \hline
\end{tabular}

\title{
PAMLICO FOSSIL ECHINOIDS
}

\section{By Willard Berry}

H. G. Richards, in his report on the Pamlico formation of the Southern Atlantic Coastal Plain, ${ }^{1}$ records the occurrence of Mellita quinquiesperforata (Leske) from the Inter-Coastal Waterway between Pungo and Alligator Rivers, Hyde County, N. C.; Core Creek Canal, Carteret County, N. C.; 15 miles northwest of Myrtle Beach, Horry County, S. C.; Waverly Mills, Georgetown, S. C.; and Cooper River, Charleston County, S. C. More detailed collecting has revealed this species to be present in considerable numbers and well preserved in Cane Patch Bay on the Inter-Coastal Waterway about 6 miles east of Myrtle Beach, Horry County, S. C. Here in addition to adult specimens there occur the immature forms shown on plate 65 , figures 3,5 , and 6 . These are not so abundant as the adult specimens, but ones of 50 to $75 \mathrm{~mm}$. are fairly common.

Associated with this species is an allied form that is referable to Encope michelini L. Agassiz, which, so as far as I know, has not previously been found fossil. Both this species and the Mellita are rather abundant and easily distinguished from each other. The heavy, rounded anterior margin and the posteriorally located apex set it apart from its associated form. The immature forms are also readily distinguished from the others, as the somewhat polygonal

\footnotetext{
${ }^{1}$ Richards, H. G., Fauna of the Pleistocene Pamlico formation of the Southern Atlantic Coastal Plain. Bull. Geol. Soc. Amer, vol. 47, pp. 1611-1656, 1926.
} 
adult outline is taken on early in life. Their habitat seems to have been the same as the present members of this species, just under the surface of the sand.

Comparison of the fossil forms with the recent material in the United States National Museum leaves no doubt as to the identity, at least of the adults. As regards the smaller stages, these are similar to the modern forms but seem somehow not very well differentiated from Mellita except in the appearance of the lunules, those in the Mellita appearing much earlier than those in the Encopes.

The Mellita is not uncommon in the Pleistocene, and its occurrence in the section here is not surprising. The Encope, on the other hand, does not now inhabit the present seas east of the Gulf of Mexico and is not known from the Atlantic coast of North America; and has not been previously reported fossil. Hence, it is of interest to report it from northern South Carolina and from Pleistocene deposits.

Fragments of either Mellita or Encope have been collected from similar deposits as far north as Alligator Cut of the Inter-Coastal Waterway in Hyde County, N. C., but so far I have been unable to identify them definitely to genus and species; they appear to be only Mellita. Definite specimens of Mellita occur in Carteret County, N. C., on the spoil piles along the Inter-Coastal Waterway in Brunswick County, N. C., near the "Sand Cut," but no definite specimens of Encope have been found. Since no specimens or definite fragments resembling Encope appear north of Cane Patch Bay, Myrtle Beach, the northern extension of Encope michelini in the Pamlico would seem to reach only to northern South Carolina.

The description follows:

\section{Genus ENCOPE L. Agassiz}

Encope L. Agassiz, Monographie des scutelles, p. 45, 1841.

ENCOPE MiChelini L. Agassiz

Plate 63, Figures 1-8; Plate 64, Figures 1-6; Plate 65, Figures 1-4, 6

Encope michelini L. Agassiz, Monographie des scutelles, p. 58, pl. 6a, figs. 9, 10, 1841.-A. Agassiz, Revision of the Echini, p. 329, pl. 12d. fig. 1, 1872.H. L. ClakK, Ann. Mag. Nat. Hist., ser. 8, vol. 7, p. 599, 1911; Mem. Mus. Comp. Zool., vol. 46, No. 1, p. 75, 1914; Papers Dept. Marine Biology, Carnegie Inst. Washington, vol. 13, No. 3, p. 73, 1919; Sci. Surv. Porto Rico and Virgin Islands, New York Acad. Sci., vol. 16, pt. 1, p. 87, 1933.Grant and Hertlein, Publ. Univ. California at Los Angeles, Math. and Phys. Sci., vol. 2, pp. 96, 99, 1938.

Specimens somewhat pentagonal in outline, with the more nearly straight portion posterior, anterior margin rounded and fairly thick, 
posterior margin about one-half thickness of anterior and somewhat sharper. Margin cut by five reentrant marginal ambulacral notches, deep and narrow, which occasionally have been observed to make a lunule (pl. 64, fig. 6). All the ambulacra are, except in the young, deep narrow notches, but the posterior notches are the deepest. The apical disk is central. The peristome is prominent and central and on the aboral surfaces rises posterially to the greatest thickness of the test about two-thirds of the distance from anterior margin and at the anterior end of the lunule of the posterior interambulacrum 5 , and just above the periproct, which is confluent with the lunule. The ambulacral petals are fairly narrow and the posterior ones are longer than the others. The oral ambulacral furrows are deep and branch toward the margin. The apical disk is well preserved, showing the pores very distinctly. The entire surface is covered with small tubercles, those on the oral surface most pronounced.

In the young the marginal ambulacra notches are shallow, although the poterior ones are more pronounced and the ambulacral furrows are indistinct. Tubercles are present over entire surface; they are more pronounced on the young ones.

The fossil specimens range in size from $23 \mathrm{~mm}$. long and $21 \mathrm{~mm}$. wide to $146 \mathrm{~mm}$. long and $144 \mathrm{~mm}$. wide, with maximum thickness $19 \mathrm{~mm}$.

For purposes of comparison I have figured a recent Encope michelini from Albatross station 2609, plate 63, figures 2, 5, and 8, and a series of fossil specimens ranging in size from $13 \mathrm{~mm}$. long (pl. 65, figs. 3, 6), to a large adult, $146 \mathrm{~mm}$. long (pl. 64, figs. 1, 3). The figured specimens are in the collection of the U. S. National Museum.

I wish to express my thanks to Austin H. Clark, of the U. S. National Museum, and to Dr. Robert T. Jackson, of Peterborough, N. H., for advice and help in arriving at the identification of these fossils. 


\section{$2 \mathrm{BHL}$ Biodiversity Heritage Library}

Berry, Willard. 1941. "Pamlico fossil echinoids." Proceedings of the United States National Museum 90(3113), 443-445.

https://doi.org/10.5479/si.00963801.90-3113.443.

View This Item Online: https://www.biodiversitylibrary.org/item/32375

DOI: https://doi.org/10.5479/si.00963801.90-3113.443

Permalink: https://www.biodiversitylibrary.org/partpdf/14467.

\section{Holding Institution}

Smithsonian Libraries

\section{Sponsored by}

Smithsonian

\section{Copyright \& Reuse}

Copyright Status: NOT_IN_COPYRIGHT

Rights: https://www.biodiversitylibrary.org/permissions/

This document was created from content at the Biodiversity Heritage Library, the world's largest open access digital library for biodiversity literature and archives. Visit BHL at https://www.biodiversitylibrary.org. 